$\underline{\text { Revised Version : October } 1999}$

\title{
The Redistributive State and Conflicts in Africa
}

\author{
by
}

\author{
Jean-Paul Azam \\ ARQADE and IDEI, University of Toulouse, \\ and Institut Universitaire de France.
}

\section{WPS/2001.3}

\begin{abstract}
This paper argues that ethnic problems are only one aspect of political violence in Africa, while violent conflicts must be thought about as a failure of the state to perform some of its fundamental tasks. State formation in Africa is a transition process starting from an institutional endowment of ethnic division. Ethnic capital in Africa ensures the provision of many services that a modern state has taken over in rich countries, including security, education, rules of behaviour, etc. Most African states are so far unable to deliver all these services adequately, and must go through an initial phase of federation of ethnic groups, before they can provide a credible substitute to ethnic capital. The system of redistribution within and among groups is the key to creating the solidarity links between them, and its breakdown is liable to trigger the eruption of political violence. Civil wars, or other forms of political violence, are thus an integral part of the political economy of Africa.
\end{abstract}

Acknowledgements : This paper has been presented as a keynote address at the annual conference of the Norwegian Association for Development Research (NFU) in Oslo, in September 1999. I wish to thank the participants for their useful comments, without implicating. 


\section{Introduction}

Tribalism and ethnic division exist in most countries, on all the continents. The recent Kosovo war has reminded us strikingly that Europe is not immune from this type of problems, and World War II involved also a clear ethnic dimension. Nevertheless, at least since 1945, ethnic violence seems to erupt most frequently in poor countries, and (Sub-Saharan) Africa has offered many examples of political violence or civil wars which have involved an ethnic or tribal dimension. However, most of the time, the reference to ethnicity is used as a readymade explanation of the eruption of civil wars, especially in the mass media, while a closer look at the facts suggests that it falls short of providing even the beginning of an explanation. For each example of an ethnically divided African country that has been victim of a civil war, one can present several examples of equally divided African countries which have managed to remain peaceful, and where all the ethnic tensions have been smoothed out in the political process, or have resulted only in extremely limited violence. In fact, only a minority of African states, although a sizeable one, have experienced serious insurgencies (Clapham, 1998), while all the African countries are ethnically divided.

This paper argues that ethnic problems are only one aspect of political violence in Africa, while violent conflicts must be thought about as resulting from a failure of the state to perform some of its fundamental tasks. State formation in Africa is a transition process starting from an institutional endowment of ethnic division. Ethnic capital ensures to most African people the provision of many services that a modern state has taken over in rich countries, including security, social insurance, education, norms of behaviour, contract enforcement, justice, etc. (see e.g. Wintrobe, 1998). Both the state and the ethnic group share some common characteristics, within different boundaries : « universal membership and compulsion » (Stiglitz, 1989, p.22). All the citizens of a country are subjects of the state that is ruling this country, and similarly, and probably even more strongly in many instances, one cannot exit from the ethnic group in which one is borne ${ }^{1}$. Both the state and the ethnic group obey some 'constitutional' rules, enforced more or less strongly by some authority. If one defines the state in a Weberian way, as having the monopoly over coercion, then one must regard the African states as being at a formation stage, as the kin group and the ethnic group do exert also some substantial coercive power. Most African states are so far unable to deliver adequately all the services that the ethnic group provides, and must go through an initial phase of federation of ethnic groups, before they can provide a credible substitute to ethnic capital. The system of redistribution within and among groups is the key to creating the solidarity links between them, and its breakdown is liable to trigger the eruption of political violence. Civil wars, or other forms of political violence, are thus an integral part of the political economy of Africa. They need to be understood for improving aid policy, and at least avoid to fuel local conflicts by providing aid in a mindless way.

The state and the ethnic groups are connected by the participation of the elite of the latter to the former. Ethnic groups, and their constituent parts kin groups, invest collectively in the out-migration of their fittest members, which generally is associated with some investment in education, with a view to get them involved in the urban elite. The education bias of migration has been documented by various researchers, like Collier and Lall (1986), for the case of Kenya. Economists have emphasised the function of insurance that results from the

\footnotetext{
${ }^{1}$ Most travellers in Africa know exceptions to this rule. I have personally known a Dogon who has become a Bozo in the course of his life, in Mali, because he wanted to make a living out of fishing, which is only open to Bozo people in that area ; it is well known that the divide between the Utu and the Tutsi in Rwanda is generally blamed on the Belgian colonial administration, as an artefact, initially based on the inequality of cattle ownership.
} 
diversification of income risk that results from migration and the ensuing flow of remittances (Lambert, 1994). Drèze and Sen (1989) have illustrated how the threat of a food crisis can trigger a flow of food help from the urban centres to the affected regions, in particular in Kenya in 1982. Even in case of milder shocks, the flow of remittances, and of gifts, maintains some links between the migrant and his group of origin.

Not less important is the fact that sending educated members of the ethnic group to the city, via the education system, is a means to ensure political participation for the group. In peaceful African countries, a sophisticated system of inclusion of the educated people from the different ethnic groups in various organisations (students unions, single party, etc.) has evolved, whereby the state purchases loyalty from the groups through their educated urbanite 'delegates'. At election times, the latter have to go back to the village for mobilising a renewed support for the state. In Côte d'Ivoire, for example, former President HouphouëtBoigny was a maestro in the art of buying the loyalty of the most active representatives of the different ethnic groups (Azam and Morrisson, 1994). Together with a policy of visible public investment in the various regions, this flow or redistribution, involving often some corruption, only regarded as 'morally wrong' by people in donor countries, provided the cement of the emerging Ivoirian nation. This country was initially endowed with a very dangerous partition into four main ethnic groups, two of them being very close to one another, in the north, all of them strongly related to groups living on the other side of it borders, together with a religious division between the Muslims in the north and the Christians in the south. Collier and Hoeffler (1998) have shown econometrically that, ceteris paribus, ethno-linguistic fractionalisation acts in a non linear fashion on the probability of civil war, with the maximum risk occurring at about two or three ethnic groups. Nevertheless, with one exception in 1970 when the Bété Kragbé Gnagbé was killed by the army, with his followers, this country avoided ethnic violence ever since independence. Probably, multi-party elections, which were introduced in 1990, result in the exclusion of a non negligible part of the elite, and are thus increasing political risk in the short run.

This illustrates that the maintenance of civil peace is one of the fundamental tasks of a development state in Africa, a task that is often neglected by more ethnically dominated governments. Milton Obote and Idi Amin, in Uganda, for example, have shown exactly the opposite behaviour to Houphouët's, by indulging in massive favoritism to the benefit of their minority ethnic group from the north, which was overwhelmingly represented in the army, and to the detriment of the majority Baganda group, resulting in a long history of civil war and atrocities (Mutibwa, 1992). Then, the ethnic group is the natural component of a rebellion against the state, as the many links that exist among its members provide an efficient way of overcoming the free-rider problems involved in mobilising a rebellion or an insurgency. This is probably why many observers blame African civil wars on ethnic division, while the failure of the state to maintain peace is the root cause of the problem. Similarly, ethnicity is the main obstacle to a 'divide-and-rule' policy, in that it unites large chunks of the society, that are hard to break up. A complication arises from the artificial African borders, which often cut through the land of some ethnic groups, so that some economic and political activities that are internal to the group, appear as cross-border activity from the perspective of the state (smuggling, etc.).

The next section presents the basic theoretical argument according to which redistribution of the state's resources is the core issue in the war/peace problem. This is done using a very simple model, which is then qualified by references to the actual experience of African countries. Section 3 discusses briefly how the ethnic group is itself based on redistribution, and how the educated elites from each group can be federated into a state, using the intra-ethnic redistribution as a means to purchase political support. This section is more 
temptative than the previous one, and aims at uncovering some interesting lines of research, by reference both to the theoretical framework presented here, and the discussion of many examples from the recent African history.

\section{Rebellion v. Redistribution : The Basic Argument}

Rebellion, or in its more extreme form, insurrection, is a dangerous endeavour, that people are going to engage in only if the expected payoff is worth taking the risk. Most models of insurrection, and in particular the seminal one by Grossman (1991), focus precisely on this trade off, and bear some similarity with rent-seeking models. Neary (1997) presents a systematic comparison between rent-seeking models and models of conflict. Azam (1995.a) uses a model of this kind to bring out the role of redistribution of the state's resources in a peace-keeping policy, with special references to conflicts in African countries (see also Azam, Berthélemy and Calipel, 1996).

\section{The Basic Model}

The basic format models the conflict between the government and the opposition as a lottery, à la Tullock (1967) : the probability of getting the prize, i.e. of taking over the state power, depends on the relative resources invested in the game by the two parties. Here, it is the probability of overthrowing the government which is a function of the resources invested by both the opposition and the government. This reflects the fundamental uncertainty of the outcome of any fight. We now discuss a variant of this model, that highlights the part played by redistribution of the state resources in maintaining peace. If $R$ is the amount of resources invested by the rebellion in the fight against the government, and if $D$ is the amount invested in repressing it by the government, then I assume that the probability of overthrowing the government is determined by the following function :

$$
\begin{aligned}
& p(R / D)=0, \text { if } R / D \leq \rho, \text { for a given } \rho>0 \text {, and } \\
& p(R / D)>0 \text {, if } R / D>\rho \text {, with } p^{\prime}(R / D)>0 \text {, and } p^{\prime} \text { ' }(R / D)<0 .
\end{aligned}
$$

This captures the idea that there are locally increasing returns to scale in rebellion, such that there is a critical mass of resources to be invested in rebellion activity before there is any chance of overthrowing the government. Define $\rho^{*}$ by $p^{\prime}\left(\rho^{*}\right) \rho^{*}=p\left(\rho^{*}\right)$. Figure 1 represents this function.

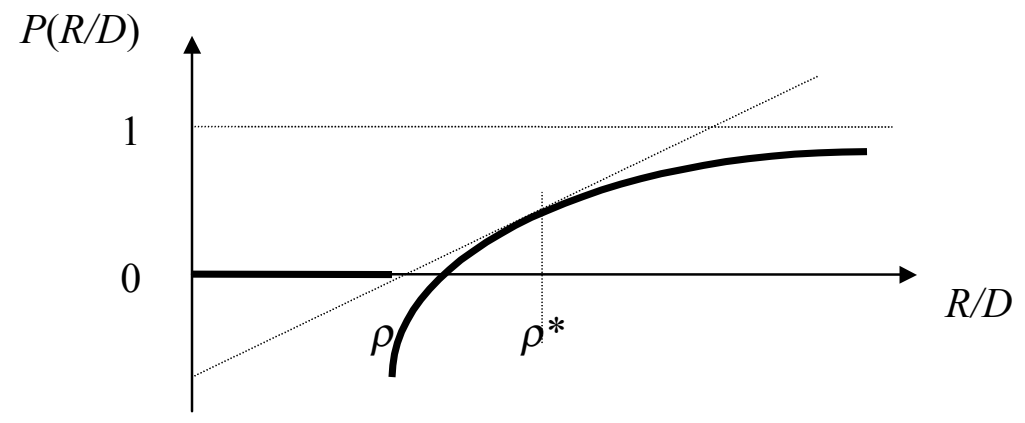

Figure 1

Then, let $T$ denote the total resources of the state, given exogenously by the taxing capacity and the available means of coercion of the state, and $G$ the amount of these resources 
that are redistributed to the people, either as social expenditures, or by other means that are discussed later. Let us emphasise here that we use a fairly broad meaning of the term 'redistribution', as it may include also the provision of public goods. What matters here is that $G$ is the public expenditures that benefit the opponent, say the people at large, when applying the model to think about a possible massive insurrection, while $T$ - $G$ represents the expenditures that benefit only the incumbent government, including its close circle of parents and allied, for the sake of realism. This might represent the type of 'white elephants' that were so common in Africa during the first two decades of independence, or the magnificent and sumptuous coronation ceremony of Emperor Bokassa I of Central Africa, or again the enormous Swiss bank accounts accumulated by Mobutu or Abacha, for example. Then, if the government is overthrown, assume that the opposition gets the whole $T$, while in the opposite case, it gets only $G$. Denote also $\omega$ the unit cost of the rebellion effort. Then, the expected profit of the rebellion is :

$$
\pi^{R}=\max _{R}\{p(R / D)(T-G)-\omega R, 0\} .
$$

Now, for an interior solution, the first-order condition reads :

$$
p^{\prime}(R / D)=\omega \frac{D}{T-G} .
$$

Then, the amount of resources invested by the rebellion is such that :

$$
\begin{aligned}
& R / D=0, \text { if } \omega \frac{D}{T-G} \geq \frac{p\left(\rho^{*}\right)}{\rho^{*}}, \\
& R / D>0, \text { if } \omega \frac{D}{T-G}<\frac{p\left(\rho^{*}\right)}{\rho^{*}},
\end{aligned}
$$

with $R=R(D, T-G)$,

$$
(+?)(+)
$$

such that :

$$
d \log R=\left(1-\frac{1}{\eta}\right) d \log D+\frac{1}{\eta} d \log (T-G),
$$

where $\eta=-\frac{p^{\prime \prime}(R / D) R}{p^{\prime}(R / D) D}$ can safely be assumed to be larger than 1 , so that $\frac{\partial R}{\partial D}>0$.

Hence, (7) gives us a rebellion function, which is predicted to be increasing with the amount of resources invested by the state in repressing the rebellion, and with the size of the cake $T$, while it is decreasing with the amount of redistribution of the state money that is forthcoming.

\section{An Econometric Test}

Azam, Berthélemy and Calipel (1996) have tested econometrically a version of equation (7), using an unbalanced panel of data from 21 African countries. The estimated equation is a probit model, where the dependent variable equals one if any violent political event, including insurrection, riots, attempted or successful coups, strikes, demonstrations, 
etc. has taken place in a given year, in a given country. This is supposed to result from a positive level of rebellion activity, irrespective of the intensity of the rebellion. In other words, it is assumed that the probability of a political event of this kind hitting the headlines of the newspapers, where the observations have been taken from, is increasing with the underlying level of rebellion activity, with low levels remaining unnoticed. The resulting equation is as follows :

$$
\begin{aligned}
& R^{*}=-38.33 S / Y+22.96 \mathrm{D} / Y-0.02 S c 1+0.03 S c 2-0.69 Z f . \\
& \begin{array}{c}
(2.16) \\
\left.N=213, \text { Pseudo }-R^{2}=0.09\right)
\end{array}
\end{aligned}
$$

In this equation, $N$ is the number of observations, $S / Y$ is the amount of public expenditures in health, as a ratio to GDP, and $S c 1$ is the enrolment ratio in primary education, both regarded as redistributive expenditures, acting with a negative impact on rebellion as predicted by the theoretical model. The other two public expenditure variables are $D / Y$, the amount of defence expenditures as a ratio of GDP, which is acting positively on the level of rebellion, as predicted by the theoretical model, and $S c 2$, the level of enrolment in secondary education, which turns out to act positively, as if the redistribution content of such expenditures was not confirmed by the African people. Maybe, secondary education has a positive impact on the probability of rebellion, because it is in fact a redistribution in favour of the middle class and the elite itself, instead of benefiting a wider audience, or because it reduces the cost of rebellion, as students are less frightened to fight the police. Lastly, $Z f$ is a dummy variable indicating whether the country is a member of the CFA franc zone. This seems to reduce the level of rebellion. We will come back on this result, the 'CFA Zone exception', later on. Despite its shortcomings, like the low value of the corresponding Pseudo$R^{2}$, or the small number of included variables supposed to represent the redistributive activity of the state, this equation seems to agree with the important role played by some public expenditures with a clear redistributive content, like public expenditures in health and education, in maintaining civil peace, that is highlighted by the theoretical model presented here.

\section{The Government Side}

Now, because of the assumed non-concavity of the $p(-)$ function, we know that the interior solution just described will not prevail in all cases. From equation (5), we find that for any given levels of $T$ and $D$, there is a high enough level of redistribution $G$, that will reduce rebellion to zero. Rearranging the terms in (5), we can write :

$$
\frac{R}{D}=0 \text { if } G \geq T-\frac{\omega \rho^{*}}{p\left(\rho^{*}\right)} D
$$

Now, whether the government will choose a public expenditure mix $\{D, G\}$ that entails a positive level of rebellion or not, depends on its objective function, but most fundamentally on its capacity to commit credibly to any pre-announced $\{D, G\}$ mix. We can show quite simply that a repression bias follows when the government plays under a credibility constraint, i.e. when it cannot pre-commit credibly to an announced policy. To see this, assume that the government seeks to maximise the expected profit from remaining in power, i.e. : 


$$
\max \pi^{G}=\left(1-p\left(\frac{R}{D}\right)\right)(T-G)-\xi D
$$

under the non-negativity constraint $G \geq 0$. Then, whether the government will take into account the equations (7) and (9) depends on the dynamics of the game, itself dependent on the capacity of the government to commit credibly. If it fails to do so, then the government and the opposition play simultaneously, and the former will maximise (10), taking as given the equilibrium amount of rebellion activity $R$. In other words, we assume in this case that, whatever the policy announced by the government, the latter will not hesitate to reverse it, once the level of rebellion activity is known, basing in fact the choice of its policy on this information. Then, under this Nash conjecture, its objective function is such that :

$$
\left(\frac{\partial \pi^{G}}{\partial G}\right)^{N}=-\left(1-p\left(\frac{R}{D}\right)\right) ; \text { and }\left(\frac{\partial \pi^{G}}{\partial D}\right)^{N}=-\xi+\left(\frac{T-G}{D}\right) p^{\prime}\left(\frac{R}{D}\right) \frac{R}{D} .
$$

Hence, under the credibility constraint, i.e. given the level of rebellion, the impact of the redistributive expenditures on the expected profit of the government is negative, so that the non-negativity constraint must be binding in equilibrium, with $G=0$. On the other hand, the impact of repression is bell-shaped, so that an interior solution is very likely to prevail in equilibrium. Notice however, from (9), that the government will never choose in equilibrium a level of repression expenditures higher than $p\left(\rho^{*}\right) T / \omega \rho^{*}$. Hence, in this case, whether or not there is a positive level of rebellion in equilibrium only depends on the level of repression chosen by the ruler, as the latter will not use redistribution as a means to reduce the threat of rebellion.

If, on the contrary, the government is able to commit credibly to an announced expenditure mix, then the government will play first, like a Stackelberg leader. Then, it engages the promised expenditure mix, and will not reverse it when the information about the level of rebellion is revealed. In this case, the government takes (7) and (9) into account, and the impacts of the two types of public expenditures on its objective functions are changed into :

$$
\frac{\partial \pi^{G}}{\partial D}=\left(\frac{\partial \pi^{G}}{\partial D}\right)^{N}-p^{\prime}\left(\frac{R}{D}\right)\left(\frac{T-G}{D}\right) \frac{\partial R}{\partial D}
$$

and

$$
\frac{\partial \pi^{G}}{\partial G}=\left(\frac{\partial \pi^{G}}{\partial G}\right)^{N}+p^{\prime}\left(\frac{R}{D}\right)\left(\frac{T-G}{D}\right) \frac{\partial R}{\partial(T-G)} .
$$

Hence, when the government is able to commit credibly, and thus plays the part of a Stackelberg leader, it takes due account of the impact of its choices on its opponent's behaviour, and this reduces the marginal profitability of repression, and increases the marginal profitability of redistribution. This confirms the existence of a repression bias when the credibility constraint is binding. Moreover, this opens the possibility that the credible government will choose an equilibrium expenditure mix with $G>0$ and $D=0$ in equilibrium, if the new terms added in (12) and (13), relative to (11) are strong enough to rotate clockwise in a strong enough way the indifference curves of the government in the $\{G, D\}$ space. This depends on the parameters of the two objective functions, and requires, inter alia, that the rebellion function be quite responsive to its two arguments. In an interior solution, the incumbent government will use both a positive level of repression and of redistribution in 
order to maintain a low enough level of investment of resources in rebellion activity by the opposition.

Therefore, the simple model presented above highlights the part played by the inability of the incumbent government to commit credibly to an announced expenditure mix, as the key to the eruption of political violence, with positive values for the resources invested wastefully in rebellion and in repression. A weak government, which is unable to commit credibly, will thus impose too much repression, and not enough redistribution, with the entailed risk of fuelling too much rebellion activity. Our distinction between a strong, or credible government, that is able to rely on redistribution for remaining in power, and a weak, or incredible government, that can only rely on repression for doing so, is akin to the distinction introduced by Rodrik (1992), between an autonomous government, with a credible capacity to commit, and a subordinate government, which does not have it. Here, the government is subordinate in the sense that its expenditure mix is dependent on the level of rebellion activity chosen by the opposition. This has implications for aid policy : without an extremely careful conditionality, a weak government will use a large share of the aid money, or an equivalent amount, to increase defence expenditures, entailing an increase in rebellion activity, while a credible one will use the additional resources with a large share devoted to redistribution. Whether the type of conditionality needed to force a weak government to use aid money to the benefit of its people is possible is a hotly debated issue (World Bank, 1998).

\section{The Sources of Credibility}

What remains to be explained, obviously, is what determines the ability of a government to commit credibly or not. In a static framework, this rests on pretty rough assumptions, which must be regarded as a convenient shorthand for some characteristics of the players that would be determined endogenously in a repeated game framework, like reputation, or the emergence of institutions that constrain the rulers to keep their words (North, 1990). Democracy, understood not so much as the existence of an electoral process for selecting the ruler, but as a set of checks and balances for protecting the rights of the minority groups, is certainly a method for achieving this outcome. However, the econometric results by Collier and Hoeffler (1999) show that democracy, as measured by the Polity III democracy scale, affects the risk of civil war in a quadratic way, with the maximum risk being found at intermediate levels. They interpret this result as showing that a gradual move to democracy, from dictatorship, would put peace at risk. Similarly, Hegre, Ellingsen, Gleditsch and Gates (1999) have found an inverted U-shaped relation between the risk of civil war and democracy. They explain this by a model where opportunity and grievances provide opposing influences on the risk of civil war. Moreover, they find that autocracies, which are more stable than semidemocracies, are in fact less stable than full democracies, so that democracy is the most probable end-point of a democratisation process, in the long run. An alternative approach to enhancing the credibility of African states is to rely on donors and conditionality to enforce it, as illustrated by Azam (1999.b), for the case of optimal seignorage. If the expected cost of reneging on its engagements is large enough, in terms of cut aid, and if the donors are really credible, then the donor community could help promote peace by subjecting the public expenditure mix to a type of conditionality that emphasises the public expenditures with a clear redistributive content, as defined here.

Nevertheless, the emphasis put by the simple model presented in this section on credibility, on the one hand, and on redistribution, on the other hand, provides a useful set of

tools for looking at the real world. However, the model is too simple and schematic to be applicable without qualifications and enrichment. In particular, the separation between the incumbent government and the opposition is more complex in the real world, where the state 
serves as a federation of diverse ethnic groups, in peaceful countries. We thus need to analyse more carefully the relative parts played by the state, and its 'rational-legal' bureaucracy, on the one hand, and the traditional hierarchy that governs the ethnic group, on the other hand.

\section{Ethnic Capital, the Urban Elite, and the Redistributive State}

Most African countries are characterised by recent settlements : for example, in the forest zone of West Africa, the population was negligible three centuries ago, and most ethnic groups have a founding myth based on some migrating ancestors. Queen Pokou, who sacrificed her newly born baby in order to achieve a safe crossing of the Comoë river, while escaping from her father's Ashanti kingdom, is remembered in all the Akan groups of Côte d'Ivoire. Even further north, among the Dogon of Mali, for example, there is a lively memory of the migrating couple that founded the group.

Internal and external migrations have been analysed thoroughly by economists, sociologists, anthropologists, demographers, etc., and seem to respond to various motivations (Stark, 1991). For example, rural-rural migrations, whereby a part of a kin group moves to another place in the same country, can have an insurance objective : by diversifying the income sources of the kin group, the latter acquires the possibility of smoothing its consumption stream in front of idiosyncratic shocks, provided the contingent transfers between the different sub-groups can be relied upon. In West Africa, and in other parts of the continent as well, migration can also be a substitute for the lack of credit, in the early part of a man's working life, as there is a social stigma attached to accepting to work for a wage in one's own village. Men have to move to a place where they are unknown, in order to find a job for a wage, if they want to accumulate money for starting a business as a self employed or as a farmer, and founding a family. Sometimes, this implies some international migration, inside Africa, or even as far away as Europe or the USA.

However, the most important flow of migrants, in a development perspective, is the flow between the rural and the urban sector. Urbanisation is parts and parcel with the development process, and is involved both in the process of industrialisation, and in the process of state formation. Cities have played an important part in the African development process, ever since the middle ages, at least, with Timbuktu and the other Sahelian kingdoms, or the Muenemutapa empire in Southern Africa, as the best known examples. However, modern African cities have been shaped to a large extent by the colonial phenomenon, which has left behind a distinctive style of 'modern sector'. The formal sector, including both the government sector and the enterprises of the formal sector, be they private or publicly owned, attracts a lot of the most educated migrants. These sectors pay the highest and most stable wages and salaries available in African countries, so that getting a job in them provides the kin group with some significant insurance services. However, this kind of jobs require usually a sizeable level of human capital. Therefore, kin groups and villages in Africa often invest collectively in the education of some of their young members, with a view to send them to the city for getting a formal sector job, with a strong preference for a job in government or in public enterprises. This is where they can extract the highest and most secure flow of income, to fuel a flow of remittances back to the village. Conversely, the restrictions on the access to education of large fractions of the population, as may happen sometimes in times of budgetary restraint, or under dictatorial rules, is often perceived by some social groups as a process of exclusion from the benefits of the modern sector. 


\section{A Federation of Ethnic Groups}

This creates the typically African organisation of the society, where the state bureaucracy and the political elite is composed of people from most of the different ethnic groups of the country, who play in fact the part of 'delegates' of their kin groups or ethnic groups. This is the phenomenon known as 'the good pupils' republic' in Francophone West Africa (Azam and Morrisson, 1994). However, this federation of 'delegates' from the different regions of the country creates among them some new links of solidarity. Although these people have been sent there to collect high and regular incomes, for funding transfers in favour of the ones stayed behind in the village, they can collude implicitly for using the taxation and coercive powers of the state for levying impersonally a lot of resources from the rural people who sent them where they are, in the first place. Bates (1981) has probably been the first one to have analysed very convincingly the way in which the states have distorted the functioning of agricultural markets, in order to secure additional resources for the urban elite. Pedersen (1997) builds on these foundations and presents a model where the state in developing countries is precisely regarded as a coalition of politically influent urban people organising the 'exploitation' of the rural people and of foreign aid. Although the distortion of various markets has been the rule, rather than the exception, in tropical Africa since the colonial days (see Collier and Lall, 1986, Azam and Daubrée, 1997), the diversity of the means used for creating profitable distortions in markets, in favour of the urban elite, has been astonishing. This has entailed, for agriculture alone, a great variety of adjustment policies, when attempts have been made to liberalise these economies for restoring the efficient functioning of markets (Azam, 1996). The foreign exchange market has also been an important means of levying resources to the benefit of the political elite, in economies with a striving parallel market (Azam, 1999.a). Hence, a perverse system has evolved, whereby the different ethnic goups send 'delegates' to the city, to collect some money from the formal sector and the government, while the coalition of educated elite members are able to extract from the people left behind, and behind the impersonal veil of anonymity of the state, much more than they send back. However, this system is also instrumental in creating the new solidarity networks that can progressively push ethnic links to a secondary role.

The African state is thus constructed, or should be so, as a means for federating the different ethnic groups, via a coalition of its elites, and thus entails two inter-linked redistribution systems. There is first a system of transfers within the ethnic or kin groups, whereby the rich migrants, who owe their human capital to some initial investment by their group, are supposed to remit a large part of their incomes back to the village, either on a regular basis, or more often, on a contingent basis, as a way to absorb some exogenous shocks. There is next a system of redistribution between the ethnic groups, through their elite, or via the government budget. While the state raises some funds by taxing the economy, in a more or less transparent way, it is supposed to share the benefits of these resources with the people. When the benefits of public expenditures are broadly distributed, the 'delegates' of the ethnic groups can, most of the time, obtain a renewed support to the state from their folks. Hence, this distinction between two types of redistribution systems enriches the set of interpretations that can be made of a redistribution-based model of the state, like the one presented in the previous section. Both types of redistribution systems raise interesting problems of organisation, and raise the possibility of a breakdown. The fact that the geographical area of many ethnic groups are cut by international borders complicates the picture. 


\section{Exclusion and Rebellion}

The ethnic redistribution system, whereby the state buys some loyalty from the social base via the remittances from the urban-based workers to their folks remaining back in the village, is rarely the cause of political violence. It is usually a well enforced mechanism, founded on the initial endowment of ethnic capital, which ensures most of the time compliance with the rules of the game. It usually forms an almost exhaustive partition of the people of the country, with very few people remaining out of it, with the exception of some migrants of foreign origin. Nevertheless, the study of some recent African conflicts provides some examples of insurrection that were triggered by the discontent of the ethnic base with the fallout from the participation of their elite to the state game.

A first instance is provided by the Tuareg movement in Mali and Niger in the early 1990s. Although this rebellion has been often presented as an ethnic problem between the Tuaregs and the other groups of Mali and Niger, a closer scrutiny shows that an important reason for this fighting was the discontent of the young jobless Tuaregs with their tribal rulers. The Ishumar (derived apparently from the French word chômeur, meaning unemployed), were former soldiers from the Libyan army, that colonel Khadafi had to fire when the oil money started to dry out. When returning to their homeland, these young Tuaregs realised that there were no opportunity for them, in particular because of the poor education that they had received, and the very poor infrastructure invested in their region by the Malian or Nigerien governments. General Moussa Traoré of Mali, had purchased the quietness of the Tuaregs by distributing some advantages to the members of the Tuareg traditional cheiftancy, with very little fallout for the rest of the people. Then, the north witnessed an insurrection, which was directed as much against the feudal leaders as against the Malian and Nigerien states (Gaudio, 1992, Azam et al., 1999). Another example of breakdown of the redistribution system within the ethnic framework is provided by the insurgency in Sierra Leone in the early 1990s, described by Abdullah and Muana (1998) as a revolt of the lumpen-proletariat. Without any ethnic support, nor any national program, the Revolutionary United Front, formed from the underclass of Freetown and the illegal diamond miners, turned into a sort of bandit movement, committing atrocities against the people from any groups. Bates (1989) provides an analysis of the Mau-mau insurgency in Kenya, in the 1950s, suggesting that it was also triggered by a breakdown of the relationship between the Kikuyu elite and its ethnic base. These examples illustrate the fact that the ethnic group can fail to provide the required link between its members and the higher levels of the state, and in this case, a type of political violence that is particularly difficult to control erupts.

Most of the time, a violent insurgency arises when one or several ethnic groups are excluded from the sharing of the state bounty. It is fairly significant to notice that the insurgent groups are very much a reflection of the structure of the ethnic groups described above: the analysis of recent guerrillas presented in Clapham (1998) shows that most insurgent groups are led by the most educated members, and that the loyalty that they get from their followers depends to a large extent on their ability to secure and redistribute resources within the group. Then, absent foreign support, which is more and more difficult to mobilise in the post-Cold War period, the looting of alien groups is often the only solution left. In some cases, looting allows some warlords to sustain long-duration insurgencies, that do not seem to aim really at toppling the government, but at creating an enclave under the control of the insurgents, in a sort of partial secession.

Among others, Pool (1998) for the case of the Eritrean People's Liberation Front, and Young (1998), for the Tigray People's Liberation Front, illustrate precisely how the educated elite members have organised the distribution of resources among their supporters, and how this has helped attracting more of them. Then, the cross-borders relationships with each other, 
as well as with southern Sudan, played a crucial role. However, in these days of the Cold War, it was relatively easy to get funding from one of the super-powers, so that looting was less necessary. Another interesting case is that of the urban rebellion that led to the overthrow of General Moussa Traoré in Mali. At the cost of about 300 deaths, the people of Bamako, and of a few other cities in Mali, have managed to overthrow the dictator, who had ruled the countries for more than two decades. The insurrection movement was in fact led by a small number of medical students, returning from several years of study abroad, mainly in Dakar. It was followed by urban people of all social origins, but the most heroic fighters were the students' mothers, hitting the soldiers with their sticks. The latter burnt the market with the customers inside, including mainly women (Azam et al., 1999). The reason for this rebellion, consistent with the theoretical framework sketched here, is that Moussa Traoré had followed a policy of gradual reduction of the state involvement in the accumulation of human capital, cutting on the social expenditures in health and education, and was thus progressively erecting some strong barriers to entry into the politically influent elite, as we have seen above that education is the key for entering in this elite.

The analysis of recent conflicts suggests that the exclusion of some threatening groups from the sharing of the resources of the state is made more likely when the country relies on mineral exports than when it relies on agricultural exports. The history of the Biafra war in Nigeria in the late 1960 is the archetype of such a war, where an ethnic group wants to secede from the country in order to exploit on its own some mining resources located in its regional area, oil in this case. This is a case where one ethnic group was trying to exclude the other two main groups from the 'loot-sharing' game. The civil wars in Angola and in the Democratic Republic of Congo provide other examples, as does Cairns (1997). Collier and Hoeffler (1999) have confirmed this assumption, that emerges from case studies, by estimating an econometric equation, a probit regression, explaining the causes of civil wars, and find that the share of mineral exports in GDP is the most important predictor of the incidence of civil wars, with a global sample. On the contrary, agricultural or industrial exports, the production of which are not located in a narrow place, and are either spread over a wider portion of the territory, belonging to various ethnic groups, or are located in urban centres, where all the different ethnic groups are mixed, do not seem to enhance the chances of civil violence erupting.

\section{The Political Economy of High Public Sector Wages}

Among the methods used by African governments to maintain peace, high public sector wages seem to play an important part. In the present framework, high public sector wages and salaries are meant to fuel a large flow of remittances between the members of the urban elite group and their fellow ethnic-group members, in order to buy some support from them. Some suggestive evidence about this role is provided by trying to enquire about the reason for the negative effect on the probability of political violence of CFA Zone membership (the 'CFA Zone exception') found at equation (8) above, from Azam, Berthélemy and Calipel (1996). Although this falls short of an adequate test of the assumption, one may conjecture that the main relevant impact of membership in the CFA Zone has been, historically, to entail much higher wages and salaries in the public sector than in other African countries, relative to income per capita. This point has been made before by van de Walle (1991), and Azam (1995.b), and is brought out vividly by looking at figure 2. It is clear from this chart that CFA Zone member countries were paying much higher wages and salaries, relative to income per capita, to their civil servants and, by contagion, to other formal sector employees, than other countries in Africa, relative to per capita GDP, at least until the 1994 devaluation of the CFA franc. 
This suggests that high public sector wages, which are purchased at the cost of a smaller number of public agents relative to the population, as shown in figure 2, are strongly associated with a more peaceful society. In other words, the private redistribution of the state money down the ethnic channel seems more important than the anonymous provision of public goods by the state. However, the example of Côte d'Ivoire, where former President Houphouët-Boigny followed a strategy of highly visible public investments in the regions peopled by the other ethnic groups, like the San Pedro port in the Béte area, or the less successful sugar complexes in the Sénoufo country, in the north of the country, which had probably a high impact on peace-keeping, leads to qualify this statement. Moreover, the CFA Zone member countries are regarded in most ratings as less corrupt than other African countries, and this may provide another channel by which high public sector wages reduce the risk of political violence. When the high incomes of the elite members are levied in an anonymous way, through the tax system, this creates less inter-ethnic resentment than petty corruption, which entails extortion by identifiable persons. This proposition is testable, by analysing whether there has been in the CFA Zone an increase in political violence, or in state collapse, since the devaluation of the CFA franc in January 1994, which is known to have reduced the relative incomes of civil servants and formal sector employees. Casual observation suggest that the coup in Niger and the emergence of near-chaos in CongoBrazzaville, where the 'Cobras', the 'Ninjas' and the 'Scorpios', seem to fight a non-sensical war, could provide some support to this idea.

In any case, whether this can be proved or not by empirical evidence, it seems that many African dictators are believing that this link exists. A historical study of Burkina Faso and of Mali (Azam et al., 1999) suggests that rulers use increases in public sector salaries as a means to buy loyalty and political support, when they feel that their position in power becomes shakier. In fact the different governments of Burkina Faso seem to have alternated between a phase of moderation of the wages and salaries of the civil servants, with high provision of public goods, at the beginning of their stay in power, and a phase of low provision of public goods, associated with rising wages and salaries of civil servants, at a later stage. The reign of General Moussa Traoré of Mali seems to display the same pattern, but at a much slower pace.

\section{Conclusion}

This paper has first presented formally the basic argument that the occurrence of civil conflicts in Africa is intimately related to the failure of the government to deliver the type of public expenditures that the people want, with a strong redistributive component, like health and education. A simple game-theoretic model has been discussed, showing that a government that is able to commit credibly to its announced public expenditure mix will resort more to redistributive public expenditures, and less to repression, than a government that can renege on its promises, once the potential opponents have reduced their involvement in rebellion activity. In a precise sense, then, a weak government implies a repression bias, while a strong government will use less repressive actions, or even will simply give them up, and will rely more on redistribution. 


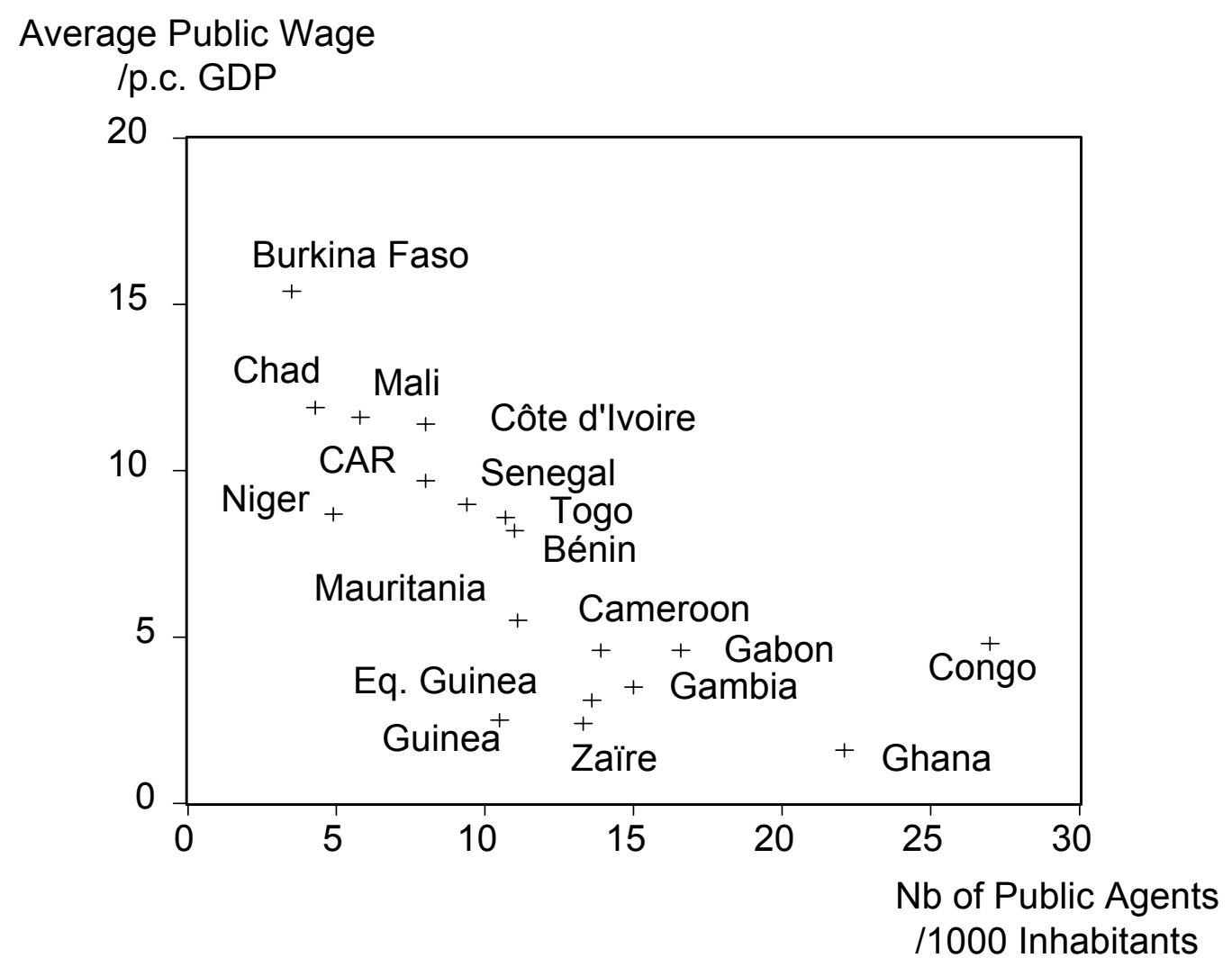

\section{Figure 2 : Relation between Public Wages and Public Employment (1987)}

Then, this general framework has been brought to bear more closely on African problems, by suggesting, by means of examples, that redistribution may appear in the real world under different guises. The fundamental problem posed to African states is to substitute state-provided services for ethnic capital, in the long run, starting with a strong endowment of the latter. Then, during a transition phase, the aim of the benevolent state is to federate the different ethnic groups, and not to destroy their role, as some 'modernisers' seem to advocate. Instead, one should aim at building on their capacities, but at a wider level. To this aim, various mechanisms of redistribution, both within and between the ethnic groups, can be used. Roughly speaking, the main problem faced by the government is to choose between two methods of buying public support : the provision of public goods with a clear and strong redistributive content, like primary education and basic health care, on the one hand, versus the payment of high wages and salaries, enabling the public agents to redistribute privately large sums of money down to their kin group, on the other hand. The experience of the CFA Zone suggests, although no formal test has been offered, that the high wage policy is pretty efficacious at buying civil peace. The benefits of this policy, in terms of peace-keeping, have to be balanced against its cost in terms of under-provision of public goods, with potentially detrimental effects on long-term growth, according to some brands of endogenous growth theory.

This line of analysis has very clear implications for aid policy. First of all, it shows that the latter must avoid by any means to undermine the process of state formation. Second, it suggests that political conditionality should emphasise checks and balances, the defence of the 
rights of minorities, etc., and not necessarily multi-party elections, which might lead to the exclusion of large parts of the people from political participation, proportional representation, which cuts representatives from direct popular control, and other formal institutions imported from the north. Conversely, it suggests that 'demonising' traditional institutions, that form the cement of most African societies, must be avoided, and the development capacities of the ethnic communities should be used, while African states are slowly groping toward their modernised forms. Lastly, it suggests that the trade-off between high wages in the public sector and the resulting under-provision of public goods must be handled with care, taking due account of the needs to purchase popular support for the state, and avoid the eruption of insurgencies.

\section{References :}

Abdullah, I. and P. Muana (1998) : « The Revolutionary United Front of Sierra Leone », in C. Clapham (ed.): African Guerrillas, 172-193, James Currey : Oxford.

Azam, J.-P. (1995.a): «How to Pay for the Peace? A Theoretical Framework with References to African Countries », Public Choice, 83, 173-184.

Azam, J.-P. (1995.b) : «L'Etat auto-géré en Afrique », Revue d'économie du développement, $1-19,1995 / 4$.

Azam, J.-P. (1996) : "The Diversity of Adjustment in Agriculture », in S. Ellis (ed.) : Africa Now, 136-154, DGIS-Heinemann-James Currey: The Hague and London.

Azam, J.-P. (1999.a) : «Dollars for Sale : Exchange Rate Policy and Inflation in Africa», World Development, 27, 1843-1859.

Azam, J.-P. (1999.b) : «Institutions for Macroeconomic Stability in Africa», Journal of African Economies, 8, 8-31.

Azam, J.-P., J.-C. Berthélemy and S. Calipel (1996) : «Risque politique et croissance en Afrique », Revue économique, 47, 819-829.

Azam, J.-P. and C. Daubrée (1997) : Bypassing the State : Economic Growth in Kenya, 19641990, Development Centre Studies, OECD: Paris.

Azam, J.-P. and Ch. Morrisson (1994): The Political Feasibility of Adjustment in Côte d'Ivoire and Morocco, Development Centre Studies, OECD: Paris.

Azam, J.-P., Ch. Morrisson, with S. Chauvin and S. Rospabé (1999) : Conflict and Growth in Africa. Vol.1 : The Sahel, Development Centre Studies, OECD: Paris.

Bates, R. H. (1981) : Markets and States in Tropical Africa, University of California Press : Berkeley.

Bates, R. H. (1989) : Beyond the Miracle of the Market: The Political Economy of Agrarian Development in Kenya, Cambridge University Press : Cambridge. 
Cairns, E. (1997) : A Safer Future : Reducing the Human Cost of War, Oxfam Publications : Oxford.

Clapham, C. (ed.) (1998) : African Guerrillas, James Currey : Oxford.

Collier, P. and A. Hoeffler (1998) : « On Economic Causes of Civil Wars », Oxford Economic Papers, 50, 563-573.

Collier, P. and A. Hoeffler (1999) : Justice-Seeking and Loot-Seeking in Civil War, mimeo, The World Bank : Washington, D.C.

Collier, P. and D. Lall (1986) : Labour and Poverty in Kenya, 1900-1980, Oxford University Press : Oxford.

Drèze, J. and A. Sen (1989) : Hunger and Public Action, Oxford University Press : Oxford.

Gaudio, A. (1992) : Le Mali (2 ${ }^{\text {nd }}$ ed.), Khartala : Paris.

Grossman, H. I. (1991) : «A General Equilibrium Model of Insurrections », American Economic Review, 81, 912-921.

Hegre, H., T. Ellingsen, N. P. Gleditsch and S. Gates (1999) : Towards a Democratic Civil Peace ? Opportunity, Grievance, and Civil War 1816-1992, mimeo, International Peace Research Institute : Oslo.

Lambert, S. (1994) : «La migration comme instrument de diversification des risques dans la famille ivoirienne ", Revue d'économie du développement, 1994, №2.

Neary, H. M. (1997) : «A Comparison of Rent-Seeking Models and Economic Models of Conflict », Public Choice, 93, 351-373.

North, D. (1990) : Institutions, Institutional Change and Economic Performance, Cambridge University Press : Cambridge, U.K.

Pedersen, K. R. (1997) : «The Political Economy of Distribution in Developing Countries : A Rent-Seeking Approach », Public Choice, 91, 373-388.

Pool, D. (1998) : «The Eritrean People's Liberation Front», in C. Clapham (ed.): African Guerrillas, 19-35, James Currey : Oxford.

Rodrik, D. (1992) : "Political Economy and Development Policy», European Economic Review (Papers \& Proceedings), 36, 329-336.

Stark, O. (1991) : The Migration of Labour, Basil Blackwell : Oxford.

Stiglitz, J. et al. (1989) : The Economic Role of the State, Bank Insinger de Beaufort NV : Amsterdam. 
Tullock, G. (1967): "The Welfare Cost of Tariffs, Monopoly, and Theft», Western Economic Journal, 5, 224-232.

Van de Walle, N. (1991): «The Decline of the Franc Zone: Monetary Politics in Francophone Africa », African Affairs, 90, 383-405.

Wintrobe, R. (1998) : The Political Economy of Dictatorship, Cambridge University Press : Cambridge.

World Bank (1998): Assessing Aid, A World Bank Policy Research Report, Oxford University Press : Oxford.

Young, J. (1998) : «The Tigray People's Liberation Front», in C. Clapham (ed.): African Guerrillas, 36-52, James Currey : Oxford.

Biographical Statement : JEAN-PAUL AZAM, b. 1951, Ph. D. in Economics (London School of Economics, 1980) and Doctorat d'Etat ès Sciences économiques (Aix-enProvence, 1982); Professor of Economics, University of Toulouse, and Institut Universitaire de France. Director of ARQADE. Current research interest: political economy of Africa. 